\title{
LITERASI DAMPAK PENGGUNAAN SMARTPHONE BAGI KEHIDUPAN SOSIAL DI DESA NGADIROJO, KABUPATEN PACITAN
}

\author{
Muchamad Rizqi, Bagus Cahyo Shah Adhi Pradana \\ Ilmu Komunikasi, Universitas 17 Agustus 1945 Surabaya \\ rizqimuchamad@gmail.com, baguspradana10@gmail.com
}

\begin{abstract}
Ngadirojo village is a village located in Ngadirojo, Pacitan. It took approximately 1 hour and 30 minutes from the center of Pacitan to reach this location. The majority of people in this village are farmers and ranchers. Nevertheless they are already aware of the media in which the majority of people in this country own and able to operate a smartphone. However, a lot of people in Ngadirojo who do not know the impact of the various communication devices they own it. In this study, researchers used a qualitative method with descriptive approach to conduct direct observation and interviews with some of the community as well as with devices Ngadirojo village. The results of this study showed that most people in the Ngadirojo village not know of the impact caused by the use of smartphones. They just use it as a medium to spread and receive information as well as entertainment without any filtration of the contents in it. If people can understand this then they will be wise in using the smartphone so that it can minimize the negative impacts caused by the development of this communications technology.
\end{abstract}

Keywords: literacy, impact of smartphones, development of communication technology

\begin{abstract}
ABSTRAK
Desa Ngadirojo merupakan salah satu desa yang terletak di Kecamatan Ngadirojo, Kabupaten Pacitan. Butuh waktu kurang lebih 1 jam 30 menit dari pusat Kota Pacitan untuk mencapai lokasi ini. Masyarakat di desa ini mayoritas memiliki mata pencaharian sebagai petani dan peternak. Meskipun demikian mereka sudah melek media di mana mayoritas dari masyarakat di desa ini sudah memiliki dan mampu mengoperasikan smartphone. Namun, banyak di antara masyarakat di Desa Ngadirojo ini yang belum mengetahui berbagai dampak yang ditimbulkan oleh perangkat komunikasi yang mereka miliki tersebut. Dalam penelitian ini peneliti menggunakan metode kualitatif dengan pendekatan deskriptif yaitu dengan melakukan observasi dan wawancara secara langsung dengan beberapa masyarakat maupun dengan perangkat Desa Ngadirojo. Hasil dari penelitian ini menunjukkan bahwa sebagian besar masyarakat di Desa Ngadirojo belum mengetahui akan dampak yang ditimbulkan oleh penggunaan smartphone. Mereka hanya menggunakannya sebagai media dalam menyebar dan menerima informasi serta hiburan tanpa ada filtrasi terhadap konten-konten di dalamnya. Apabila masyarakat dapat memahami hal ini maka mereka akan bijak dalam menggunakan smartphone sehingga dapat meminimalisir dampak negatif yang diakibatkan oleh perkembangan teknologi komunikasi ini.
\end{abstract}

Kata kunci: literasi, dampak smartphone, perkembangan teknologi komunikasi 


\section{PENDAHULUAN}

Menurut Asosiasi Penyelenggara Jasa Internet Indonesia (2017), data pengguna internet di Indonesia dalam tiga tahun terakhir, yakni pada tahun 2015 sebanyak 110,2 juta orang, tahun 2016 (132,7 juta orang) dan tahun 2017 sebanyak 143,7 juta orang 54, 68 \% dari penduduk Indonesia (262 juta orang).

Sejak awal Januari 2018, beberapa laporan pun dirilis tentang apa yang terjadi di tahun sebelumnya 2017. Tentang pengguna internet di Indonesia, seperti dirilis di wearesocial tentang Global Digital Report 2018, terjadi beberapa peningkatan pengguna digital di Indonesia. Dari Total Populasi 265 Milyar penduduk Indonesia, setengah nya atau 50\% sebesar 132 Milyar penduduknya sudah menggunakan internet dalam aktivitas keseharian mereka.

Kemajuan teknologi adalah sesuatu yang tidak bisa dihindari dalam kehidupan ini, hal itu berjalan seiring dengan kemajuan ilmu pengetahuan. Teknologi juga memberikan banyak kemudahan, serta sebagai cara baru dalam melakukan aktivitas manusia. Manusia juga sudah menikmati banyak manfaat yang dibawa oleh inovasi-inovasi teknologi yang telah dihasilkan dalam dekade terakhir ini.

Perkembangan teknologi terutama pada teknologi komunikasi membawa kehidupan ini ke arah yang lebih baik. Namun, apakah perkembangan teknologi komunikasi ini benarbenar membawa kita ke kehidupan yang lebih baik? Pola komunikasi masyarakat mengalami perubahan yang sangat hebat dalam beberapa tahun belakangan ini.

Era '90-an handphone sudah menjadi alat komunikasi yang paling canggih. Saat ini, fungsi itu sudah bergeser dari semula sebagai alat komunikasi menjadi sebuah perangkat yang memiliki berbagai macam fungsi mulai dari fungsi utama sebagai alat komunikasi hingga pada entertainment dan sangat wajar jika dunia menyebutnya smartphone. Segala aktivitas kita mampu ditopang oleh sebuah perangkat bernama smartphone ini sehingga arus lalu lintas pesan yang terjadi sangat luar biasa.

Teknologi komunikasi memiliki pengaruh yang sangat kuat dalam membius manusia untuk tunduk padanya dan mengabaikan yang lain. Jika manusia tidak sadar akan hal ini, maka dia akan kesepian dan kehilangan sesuatu yang amat penting dalam dirinya, yakni kebersamaan, hubungan kekeluargaan, dan sosial yang hangat. Jika pengaruh teknologi yang demikian semakin dalam, manusia tidak sadar akan kebutuhan yang sebenarnya. Manusia tidak bisa menipu diri sendiri akan kenyataan bahwa teknologi mendatangkan berbagai dampak bagi dirinya termasuk dampak negatif yang diakibatkannya. Kemajuan teknologi, yang semula untuk memudahkan manusia, ketika urusan itu semakin mudah, selanjutnya muncul sebuah keterasingan baru, yakni lunturnya rasa solidaritas, kebersamaan, dan silaturrahmi. Akibatnya, kita terlena dengan perangkat yang kita 
genggam. Smartphone kemudian menjadi teman setia, bahkan kita lebih memperhatikannya dibandingkan teman, sahabat, bahkan tidak menutup kemungkinan istri/suami, dan anak sekalipun. Hampir setiap bangun tidur kita rela memeriksa perangkat komunikasi kita baik untuk berkirim pesan maupun bermain aplikasi yang disediakan di dalamnya. Inilah yang membuat manusia mengalami sebuah kondisi dimana ia lupa dengan kehidupan sosialnya.

Perkembangan teknologi komunikasi sangat membantu masyarakat di baik di desa maupun di kota. Roda perekonomian, aktivitas belajar mengajar, serta sistem pemerintahan saat ini mulai bergantung pada teknologi komunikasi. Mereka menganggap perkembangan teknologi komunikasi sangat mereka butuhkan untuk menyokong aktivitas sehari-hari. Tidak hanya dampak positif yang dirasakan oleh masyarakat di desa tersebut tapi juga dampak negatif juga tak kalah menakutkan.

Perubahan perilaku sosial, pola komunikasi, hingga penurunan prestasi belajar juga dirasakan oleh sebagian besar orang tua bahkan, sebagian dari mereka menyayangkan anak-anak mereka yang tidak bisa lepas dari smartphone. Alasannya sederhana, yakni mereka tidak ingin melewatkan satupun informasi yang terkirim melalui smartphone mereka. Sebagian besar hanya berimajinasi sesuai dengan apa yang ditayangkan di perangkat komunikasi yang mereka miliki dan inilah yang dikhawatirkan terutama pada anak-anak yang belum mampu membedakan antara yang nyata dan visual. Banyak yang belum memahami akan dampaknya bagi kepribadian anak.

Maraknya berbagai fenomena negatif tersebut direspon dengan keresahan oleh berbagai kalangan masyarakat, serta telah membuktikan bahwa keberadaan kita yang selalu dekat dari media tidak diiringi dengan kemampuan untuk melakukan literasi media atau mengkritisi pesan yang disampaikan oleh media dengan baik, sehingga masyarakat asalasalan dalam menanggapi berbagai pesan yang disampaikan oleh media. Kejadian semacam ini bukanlah sesuatu yang aneh jika melihat berbagai faktor yang ada, diantaranya yaitu kecanggihan media yang bisa berinteraksi tanpa harus bertatap muka sehingga remaja bisa bebas berinteraksi tanpa berpikir secara matang, pemberitaan media yang mereduksi fakta dapat menghasilkan kenyataan semu sehingga remaja sulit dalam membedakan mana pesan yang benar dan tidak.

Manusia saat ini benar-benar telah menjadi budak dari teknologi. Berdasarkan survei yang dilakukan Secur Envoy, sebuah perusahaan yang mengkhususkan diri dalam password digital, yang melakukan survei terhadap 1.000 orang di Inggris menyimpulkan bahwa mahasiswa masa kini mengalami nomophobia, yaitu perasaan cemas dan takut jika tidak bersama telepon selulernya. Hasil survei menunjukkan, 66 persen responden mengaku tidak bisa hidup tanpa telepon selulernya. Persentase ini semakin membengkak pada responden berusia 18 dan 24 tahun. Sebanyak 77 persen responden di antara kelompok usia ini mengalami nomophobia (http://kampus.okezone.com/read/2012/03/26 dalam Muhamad Ngafifi). 


\section{TINJAUAN PUSTAKA}

\section{Konsep Teknologi}

Pada awalnya teknologi berkembang secara lambat. Namun seiring dengan kemajuan tingkat kebudayaan dan peradaban manusia perkembangan teknologi berkembang dengan cepat. Semakin maju kebudayaannya, semakin berkembang teknologinya karena teknologi merupakan perkembangan dari kebudayaan yang maju dengan pesat (Adib, 2011, p.254).

Secara harfiah teknologi berasal dari bahasa Yunani, yaitu "tecnologia" yang berarti pembahasan sistematik mengenai seluruh seni dan kerajinan. Istilah tersebut memiliki akar kata "techne" dalam bahasa Yunani kuno berarti seni (art), atau kerajinan (craft). Dari makna harfiah tersebut, teknologi dalam bahasa Yunani kuno dapat didefinisikan sebagai seni memproduksi alat-alat produksi dan menggunakannya.

Definisi tersebut kemudian berkembang menjadi penggunaan ilmu pengetahuan sesuai dengan kebutuhan manusia. Teknologi dapat pula dimaknai sebagai "pengetahuan mengenai bagaimana membuat sesuatu (know-how of making things) atau "bagaimana melakukan sesuatu" (know-how of doing things), dalam arti kemampuan untuk mengerjakan sesuatu dengan nilai yang tinggi, baik nilai manfaat maupun nilai jualnya (Martono, 2012, p.276).

Ilmu pengetahuan (body of knowledge) dan teknologi merupakan sebuah seni (state of $a r t$ ) yang mengandung pengertian berhubungan dengan proses produksi; menyangkut cara bagaimana berbagai sumber, tanah, modal, tenaga kerja, dan keterampilan dikombinasikan untuk merealisasikan tujuan produksi. "secara konvensional mencakup penguasaan dunia fisik dan biologis, tetapi secara luas juga meliputi teknologi sosial, terutama teknologi sosial pembangunan sehingga teknologi itu adalah metode sistematis untuk mencapai setiap tujuan Insani". (Dwiningrum, 2012, p.153).

Teknologi merupakan jawaban atas pemikiran manusia menjadi alat untuk membantu memecahkan persoalan yang ada. Teknologi diharapkan dapat menjadi fasilitator dan interpreter. Namun, tidak dapat dipungkiri bahwa perubahan dan perkembangan teknologi akan berdampak pada kehidupan sosial yang ada hingga mempengaruhi aspek yang lebih besar lagi yakni kebudayaan. Ia memiliki makna yang lebih mendalam daripada peralatan. Teknologi menetapkan suatu kerangka bagi kebudayaan nonmaterial suatu kelompok.

Jika teknologi suatu kelompok mengalami perubahan, maka cara berpikir manusia juga akan mengalami perubahan. Hal ini juga berdampak pada cara mereka berhubungan dengan yang lain. Bagi Marx, teknologi merupakan alat, dalam pandangan materialisme 
historis hanya menunjuk pada sejumlah alat yang dapat dipakai manusia untuk mencapai kesejahteraan.

Sedangkan Weber mendefinisikan teknologi sebagai ide atau pikiran manusia itu sendiri. Sementara itu menurut Durkheim, teknologi merupakan kesadaran kolektif yang bahkan diprediksi dapat menggantikan kedudukan agama dalam masyarakat (Martono, 2012, pp.277-278).

Teknologi memperlihatkan fenomenanya dalam masyarakat sebagai hal impersonal dan memiliki otonomi mengubah setiap bidang kehidupan manusia menjadi lingkup teknis. Sastrapratedja (Dwiningrum, 2012, p.154) menjelaskan bahwa fenomena teknik pada masyarakat kini, memiliki ciri-ciri sebagai berikut:

a. Rasionalitas, artinya tindakan spontan oleh teknik diubah menjadi tindakan yang direncanakan dengan perhitungan rasional

b. Artifisialitas, artinya selalu membuat sesuatu yang buatan tidak alamiah.

c. Otomatisme, artinya dalam hal metode, organisasi, dan rumusan dilaksanakan serba otomatis. Demikian pula dengan teknik mampu mengeliminasikan kegiatan non-teknis menjadi kegiatan teknis.

d. Teknik berkembang pada suatu kebudayaan

e. Monisme, artinya semua teknik bersatu, saling berinteraksi dan saling bergantung.

f. Universalisme, artinya teknik melampaui batas-batas kebudayaan dan ideologi, bahkan dapat menguasai kebudayaan.

g. Otonomi, artinya teknik berkembang menurut prinsip-prinsip sendiri

Dengan segala kemudahan yang diberikan oleh teknologi, maka masyarakat seolah dimanjakan oleh ketersediaan segala kebutuhan hidupnya. Masyarakat pengguna teknologi kian enggan untuk menggunakan alat-alat manual untuk alasan efektivitas dan efisiensi. Masyarakat semakin sulit melepaskan diri dari serba kecanggihan teknologi dan hal ini akan terus berlangsung dalam waktu lama dan kian membawa masyarakat pada ketergantungan pada pemanfaatan teknologi. Sesuatu yang berlangsung lama inilah yang menyebabkan perubahan kebudayaan pada suatu masyarakat.

Hal ini tampaknya yang menjadi alasan utama mengapa manusia enggan berpaling dari teknologi. Awal perkembangan teknologi yang sebelumnya merupakan bagian dari ilmu atau bergantung dari ilmu, sekarang ilmu dapat pula bergantung dari teknologi. Contohnya dengan berkembang pesatnya teknologi komputer dan satelit ruang angkasa, maka diperoleh pengetahuan baru dari hasil kerja kedua produk teknologi tersebut (Dwiningrum, 2012, p.155).

Era modern seperti saat ini memang sangat diidentikkan dengan era masyarakat digital. Hampir setiap aktivitas manusia digerakkan melalui teknologi digital. Teknologi ini dioperasikan hanya dengan menekan beberapa tombol yang ada di dalam perangkat 
komunikasi yang mereka miliki. Relasi yang terbangun di antara individu inilah yang disebut dengan relasi pertukaran digital, setiap manusia hanya melakukan serangkaian transaksi atau interaksi melalui simbol-simbol digital. Transaksi perdagangan, komunikasi, semuanya digerakkan secara digital.

\section{Teori Perubahan Sosial Budaya}

Gillin dan Gillin, mengartikan bahwa perubahan sosial adalah suatu variasi dari cara hidup yang telah diterima, baik karena perubahan-perubahan kondisi geografis, kebudayaan material, komposisi penduduk, dan ideologi maupun karena adanya difusi ataupun penemuan-penemuan baru dalam masyarakat.

Sementara itu, Larson dan Rogers, mengemukakan pengertian tentang perubahan sosial yang dikaitan dengan adopsi teknologi yaitu perubahan sosial merupakan suatu proses yang berkesinambungan dalam suatu bentangan waktu tertentu. Pemakaian teknologi tertentu oleh suatu warga masyarakat akan membawa suatu perubahan sosial yang dapat diobservasi lewat perilaku anggota masyarakat yang bersangkutan.

Gejala-gejala yang dapat mengakibatkan perubahan sosial memiliki ciri-ciri antara lain (Martono, 2012, p.13):

1) Setiap masyarakat tidak akan berhenti berkembang karena mereka mengalami perubahan baik lambat maupun cepat.

2) Perubahan yang terjadi pada lembaga kemasyarakatan tertentu akan diikuti dengan perubahan pada lembaga-lembaga sosial lainnya.

3) Perubahan sosial yang cepat dapat mengakibatkan terjadinya disorganisasi yang bersifat sementara sebagai proses penyesuaian diri.

4) Perubahan tidak dibatasi oleh bidang kebendaan atau bidang spiritual karena keduanya memiliki hubungan timbal balik yang kuat.

Dari definisi perubahan di atas dapat disimpulkan bahwa perubahan sosial budaya merupakan suatu perubahan yang menyangkut banyak aspek dalam kehidupan seperti kesenian, ilmu pengetahuan, teknologi, aturan-aturan hidup berorganisasi, dan filsafat. Jadi, teknologi merupakan salah satu faktor yang berpengaruh terhadap terjadinya perubahan sosial budaya. Perubahan sosial mempunyai tiga dimensi, yaitu struktural, kultural, dan interaksional. Pertama, dimensi struktural mengacu pada perubahanperubahan dalam bentuk struktur masyarakat, menyangkut perubahan dalam peranan, munculnya peranan baru, perubahan dalam struktur kelas sosial, dan perubahan dalam lembaga sosial. Kedua, dimensi kultural mengacu pada perubahan kebudayaan dalam masyarakat. Perubahan ini meliputi:

1) Inovasi kebudayaan, merupakan komponen internal dalam suatu masyarakat. Inovasi kebudayaan yang paling mudah ditemukan adalah munculnya teknologi baru. Kebutuhan masyarakat yang semakin kompleks memaksa individu untuk berpikir kreatif dalam upaya untuk memenuhi kebutuhan tersebut. 
2) Difusi, merupakan komponen eksternal yang mampu menggerakkan terjadinya perubahan sosial. Sebuah kebudayaan mendapatkan pengaruh dari budaya lain, kemudian memicu perubahan kebudayaan dalam masyarakat yang "menerima" unsur-unsur budaya tersebut.

3) integrasi, merupakan wujud perubahan budaya yang "relatif lebih halus". Hal ini disebabkan dalam proses ini terjadi penyatuan unsur-unsur kebudayaan yang saling bertemu untuk kemudian memunculkan kebudayaan baru sebagai hasil penyatuan berbagai unsur-unsur budaya tersebut (Martono, 2012, p.6).

Ketiga, dimensi interaksional mengacu pada adanya perubahan hubungan sosial dalam masyarakat. Dimensi ini meliputi (Martono, 2012, pp.7-8):

1) Perubahan dalam frekuensi. Perkembangan teknologi telah menyebabkan berkurangnya frekuensi individu untuk saling bertatap muka. Semua kebutuhan untuk berinteraksi dapat dipenuhi dengan memanfaatkan teknologi.

2) Perubahan dalam jarak sosial. Perkembangan teknologi informasi dan komunikasi telah menggeser fungsi "tatap muka" dalam proses interaksi. Individu tidak harus bertatap muka untuk dapat melakukan komunikasi dan interaksi secara langsung. Bahkan ketika dua individu berada di tempat yang sangat jauh, mereka bisa tetap berkomunikasi meskipun dalam jarak ribuan kilometer.

3) Perubahan perantara. Mekanisme kerja individu dalam masyarakat modern banyak bersifat serba online, menyebabkan individu tidak banyak membutuhkan orang lain dalam proses pengiriman informasi. Pada zaman dulu, seorang raja yang ingin menyampaikan berita untuk kerajaan tetangga, menyuruh prajurit untuk menyampaikan surat ke kerajaan tetangga tersebut. Namun, pada masa modern sekarang, informasi antar negara dapat langsung disampaikan tanpa melalui orang lain sebagai perantara.

4) Perubahan dari aturan atau pola-pola. Banyak aturan serta pola-pola hubungan yang mengalami perubahan seiring perkembangan masyarakat. Emansipasi perempuan dalam dunia kerja misalnya, telah mengubah cara pandang masyarakat.

Perubahan sosial terbagi atas dua wujud, yakni perubahan dalam arti kemajuan (progress) atau menguntungkan dan perubahan dalam arti kemunduran (regress) yaitu yang membawa pengaruh kurang menguntungkan bagi masyarakat. Jika perubahan sosial dapat bergerak ke arah suatu kemajuan, masyarakat akan berkembang. Sebaliknya, perubahan sosial juga dapat menyebabkan kehidupan masyarakat mengalami kemunduran. Kemajuan teknologi di satu sisi merupakan contoh perubahan sosial yang bersifat kemajuan karena mempermudah aktivitas manusia dalam memenuhi kebutuhan hidupnya. Namun, di sisi lain kemajuan teknologi juga merupakan contoh perubahan sosial yang bersifat kemunduran karena manusia menjadi tergantung dengan teknologi (budak teknologi) bukan manusia yang menguasai teknologi akan tetapi teknologi yang menguasai manusia. 


\section{Perubahan Pola Hidup}

Menurut Talcott Parson (Dwiningrum, 2012, p.51), masyarakat modern digambarkan dengan ciri-ciri sebagai berikut:

a. Netralitas efektif yaitu bersikap netral, bahkan dapat menuju sikap tidak memperhatikan orang lain atau lingkungan.

b. Orientasi diri, yaitu lebih mengutamakan kepentingan diri sendiri.

c. Universalisme, yaitu menerima segala sesuatu dengan obyektif

d. Prestasi, yaitu masyarakatnya suka mengejar prestasi.

e. Spesifitas, yaitu berterus terang dalam mengungkapkan segala sesuatu.

Peran teknologi dalam mempengaruhi perubahan pola hidup manusia bukanlah sebuah hal yang perlu dipertanyakan lagi. Manusia tidak akan mampu hidup tanpa teknologi. Manusia purba, misalnya, telah lama mengenal teknologi sebagai alat bantu untuk memenuhi kebutuhan hidupnya, kebanyakan teknologi itu terbuat dari bahanbahan atau materi yang sangat sederhana. Teknologi dapat menyatukan masyarakat, dapat pula memisahkan masyarakat.

Terdapat empat perubahan kecenderungan berpikir yang diakibatkan oleh perkembangan teknologi, yaitu: pertama, tumbuhnya reifikasi, yaitu anggapan bahwa yang semakin luas dalam kenyataan harus diwujudkan dalam bentuk-bentuk lahiriah. Kedua, manipulasi yaitu kemampuan manipulasi yang tinggi bagi kerangka berpikir manusia yang disebabkan kemampuan teknologi dalam mengubah dan mengolah bendabenda alamiah menjadi sesuatu yang bersifat artifisial demi memenuhi kepentingan manusia. Ketiga, fragmentasi, yaitu adanya spesialisasi dalam pembagian kerja yang akhirnya menuntut profesionalisme dalam dunia kerja. Keempat, individualisasi, yang dicirikan dengan semakin renggangnya ikatan seseorang dengan masyarakatnya dan semakin besarnya peranan individu dalam tingkah laku sehari-hari (Martono, 2012, p.278).

\section{Literasi Media}

Teknologi bagai dua sisi mata uang dimana ia memiliki pengaruh positif dan negatif sehingga masyarakat benar-benar dituntut untuk mampu mengendalikan dirinya agar pengaruh teknologi komunikasi tidak dominan dalam mengendalikan kehidupannya.

Menurut Baran \& Denis dalam Tamburaka (2013), literasi media merupakan suatu rangkaian gerakan melek media, yaitu gerakan melek media dirancang utuk meningkatkan kontrol individu terhadap media yang mereka gunakan untuk mengirim dan menerima pesan. Melek media dilihat sebagai ketrampilan yang dapat dikembangkan dan berada dalam sebuah rangkaian dimana kita tidak melek media dalam semua situasi, setiap waktu dan terhadap semua media. Berdasarkan pernyataan tersebut dapat diketahui bahwa literasi media merupakan suatu upaya yang dilakukan individu supaya mereka sadar terhadap berbagai bentuk pesan yang disampaikan oleh media, serta 
berguna dalam proses menganalisa dari berbagai sudut pandang kebenaran, memahami, mengevaluasi dan juga menggunakan media.

Jika dilihat dari Individual Competence Framework dari Final Report Study on Assessment Criteria for Media Literacy Level (2009) yang diselenggarakan oleh European Commission, kemampuan literasi media merupakan kapasitas individu yang berkaitan dengan melatih keterampilan tertentu (akses, analisis, komunikasi). Kompetensi ini ditemukan dalam satu bagian yang lebih luas dari kapasitas yang

meningkatkan tingkat kesadaran, kekritisan dan kapasitas kreatif untuk memecahkan permasalahan. Kompetensi Individual competences memiliki tiga variabel, yaitu kemampuan individu yang terdiri dari technical skill dan critical understanding, serta kompetensi sosial yang berupa communicative abilities. Berikut merupakan penjelasan ketiga faktor tersebut :

\section{Kemampuan Personal}

a. Technical Skills

Pada tataran ini, seorang individu mampu menggunakan media sosial untuk dapat dimanfaatkan. Menurut Individual Competence Framework, technical skill merupakan kemampuan teknik dalam menggunakan media internet khususnya media sosial, di mana seseorang dapat mengakses dan mengoperasikan media sosial secara tepat.

b. Critical Understanding

Menurut Individual Competence Framework, dalam tataran ini merupakan kemampuan kognitif dalam menggunakan media seperti kemampuan memahami, menganalisis, dan mengevaluasi konten media sosial secara komprehensif. Berikut ini dijelaskan berbagai dimensi tentang critical understanding:

- Understanding media content and its functioning, di mana individu dapat memahami pesan yang disampaikan oleh media. Selain itu juga ada kemampuan memahami konten dan fungsi media yang lebih ditekanan pada media sosial. Dalam hal keaktifan individu untuk mencari keakuratan informasi juga dijelaskan oleh Tibbo (2003), di mana proses pengecekan informasi dapat disebut sebagai verifying, di dalamnya terdapat proses menilai serta memeriksa keakuratan informasi.

- Pengetahuan tentang regulasi media (knowledge about media and media regulation), merupakan pengetahuan tentang undang undang yang menekankan kesadaran terhadap peraturan dan fungsi dari media. Ukuran media literacy berdasarkan European Commission 2009 dapat diukur dari pengetahuan tentang undan-gundang tentang media, akan tetapi juga dijelaskan bahwa yang lebih penting adalah bagaimana prilaku dalam memanfaatan media sosial. Sementara itu pengetahuan tentang literasi media juga di jelaskan oleh Levin (1988), bahwa awal pendidikan literasi 
media akan ditekankan oleh orang tua untuk menekankan nilai dalam memilih program, serta pengaturan media.

- Perilaku pengguna media sosial (uses behavior), menurut Individual Competence Framework (2009) dijelaskan bahwa perilaku menggunakan media dapat memberikan wawasan dalam menyikapi media seperti pengecekan informasi baru dan juga tampilan identitas dalam akun media sosial. Menurut Ellis (1989), melakukan pengawasan terhadap informasi yang mutakhir itu penting, dia menyebut hal tersebut sebagai proses monitoring. Proses tersebut dilakukan untuk mengikuti serta menjaga perkembangan informasi terbaru dalam suatu bidang dengan cara berkala. Sementara itu terkait dengan pengisian data identitas juga dibahas oleh Littlejohn (2009), bahwa seseorang yang terlibat dalam hubungan akan mengatur batasan pada dirinya terkait dengan apa yang bersifat umum dan pribadi, serta apa yang seharusnya di tampilkan dan tidak.

\section{Kompetensi Sosial}

Communicative abilities, dalam hal ini dijelaskan bahwa seorang individu mempunyai kemampuan membangun relasi sosial serta berpartisipasi dalam masyarakat melalui media sosial. Kemampuan tersebut dapat dilihat dari pemanfaatan media sosial seperti chatting, berkomentar maupun menulis status. Sedangkan menurut Horrigan, penggunaan fitur seperti komentar dan chatting merupakan bagian dari kesenangan yang didapatkan dari media sosial. Bentuk kemampuan komunikasi juga diungkapkan oleh Yusup (2010), di mana komunikasi dapat diartikan sebagai hubungan sosial yang dinamis antara perorangan, kelompok dengan kelompok, dan juga perorangan dengan kelompok. Selanjutnya Yusuf juga menjelaskan bahwa bentuk komunikasi tersebut bisa berupa hubungan sosial dengan kontak langsung atau face to face (hubungan sosial primer), ataupun hubungan melalui perantara seperti media sosial (hubungan sosial sekunder).

Citizen participation, mencakup partisipasi dalam menanggapi berbagai status maupun artikel dalam media sosial. Dalam menanggapi berbagai pesan tersebut juga perlu dilihat suatu penekanan gaya penulisan. Derk, Bos, dan Von Grumbkow (2008) menyatakan bahwa menggunakanemoticon ketika berinteraksi melalui media sosial dapat dijadikan sebagai pengganti nonverbal yang berfungsi sebagai perilaku tatap muka yang dilakukan secara online dan juga memiliki dampak interpretasi sebuah pesan.

Content creation, dalam hal ini individu mampu untuk mengkreasikan media sosial. Individual Competence Framework menjelaskan bahwa mengkreasikan konten adalah bentuk dari menampakkan diri, dapat berupa penggunaan alat komunikasi yang ada dalam media sosial tersebut dan juga beberapa hal teknis yang kompleks.

Pemahaman lain tentang mengkritisi media sebenarnya juga diulas oleh Dauglas Kellner (2010), di mana masyarakat dapat menolak pengaruh pesan yang dominan dalam media 
dan penciptanya serta pemanfaat individu. Media dapat difilter dengan menggunakan budaya yang dimiliki oleh masyarakat sebagai sumber pemberdayaan diri dan menciptakan makna identitas dan bentuk kehidupan mereka, sehingga dapat diartikan bahwa masyarakat khususnya remaja dalam hal memanfaatkan juga dapat menolak isi pesan yang disampaikan oleh media, oleh sebab itu dibutuhkan sikap kritis dan juga melakukan filter terhadap isi pesan yang disampaikan oleh media.

\section{Menangkal Dampak Negatif}

Kemajuan teknologi merupakan bagian dari konsekuensi modernitas dan upaya eksistensi manusia di muka bumi. Oleh karena itu, dampak negatif yang timbul sebagai akibat dari kemajuan teknologi menjadi kewajiban bersama umat manusia untuk mengatasinya. Dengan adanya consciousness (kesadaran) bersama maka kita yakin bahwa generasi mendatang akan lebih smart dan bermartabat. Berikut ini diuraikan peran yang semestinya dilakukan oleh keluarga, sekolah (institusi pendidikan), masyarakat, dan negara untuk menekan serta mengatasi pengaruh negatif dari kemajuan teknologi pada masyarakat postmodern. Adapun peran keluarga diantaranya sebagai berikut.

1) Sebagai agen sosialisasi yang pertama dan yang utama, keluarga seharusnya dapat menanamkan nilai dan norma yang positif kepada anak dengan membekali dan meletakkan pondasi keimanan yang kokoh kepada anak. Hal ini dimaksudkan agar anak tidak menjadi angkuh dan melupakan Tuhan dalam aktifitas kehidupan modern yang serba canggih.

2) Keluarga harus selektif dalam menentukan skala prioritas kebutuhan teknologi bagi keluarga. Hal ini dilakukan dalam upaya untuk mengurangi cara hidup manusia modern yang cenderung konsumtif terhadap produk teknologi. Selain itu, penentuan skala prioritas diperlukan agar teknologi yang dipergunakan benarbenar memberikan manfaat yang besar bagi keluarga. Misalnya, jika suatu keluarga sudah memiliki sebuah televisi mereka tidak perlu membeli televisi untuk setiap anggota keluarga yang diletakkan di kamar masing-masing, karena hal itu akan mengakibatkan pemborosan dan merupakan pola hidup yang tidak efektif dan efisien.

3) Orang tua harus update terhadap perkembangan teknologi sehingga mereka tidak gaptek. Setidaknya orang tua modern saat ini harus memiliki kemampuan dalam penggunaan smartphone, internet basic (email, browsing, blogging, and chating), dan jika memungkinkan penggunaan sosial media online seperti: Yahoo Messenger, Facebook, Twitter, Skype, dan internet relay chatting.

4) Perlunya bimbingan dan pengawasan dari orang tua kepada anak-anaknya dalam pemanfaatan teknologi, khususnya teknologi informasi dan komunikasi seperti televisi, handphone, komputer dan internet. Upaya ini dapat dilakukan dengan cara sebagai berikut:

a. Membatasi saluran (channel) televisi yang masuk agar tayangan-tayangan yang membawa dampak negatif bagi anak terutama pornografi, dan kekerasan tidak dengan mudah diterima oleh anak-anak kita. 
b. Mendampingi anak saat menonton televisi sehingga kita dapat mengarahkan anak bahwa tidak semua yang dilihat di layar kaca merupakan kejadian yang sesungguhnya.

c. Orang tua melakukan pengecekan handphone anak secara insidental untuk memastikan bahwa mereka memanfaatkan teknologi komunikasi secara benar dan bertanggungjawab.

d. Berusaha meletakkan komputer dan saluran internet di ruang publik rumah seperti di ruang keluarga bukan di dalam kamar anak. Hal ini dimaksudkan agar anak-anak lebih mudah diawasi oleh orang tua. e) Mem-blok situs-situs internet yang berbahaya bagi perkembangan anak.

e. Orang tua ikut menjadi teman anak dalam social media online.

f. Membuat kesepakatan dengan anak tentang waktu bermain komputer dan internet. Hal ini diperlukan agar ketika mereka dewasa dapat disiplin dan mampu melakukan manajemen waktu dengan baik. Selain itu, kesepakatan tentang waktu dapat mencegah anak dari kecanduan terhadap komputer dan internet serta dapat menghemat pengeluaran.

5) Orang tua meluangkan waktu untuk berkumpul, bermain, dan bercengkrama dengan anggota keluarga. Dengan demikian akan terjalin interaksi yang baik sehingga harmonisasi hubungan dalam keluarga dapat terjaga.

6) Menumbuhkan kesadaran kepada anak tentang dampak negatif dari teknlogi bagi kehidupan mereka di masa depan. Upaya ini dapat dilakukan dengan memberikan kebebasan kepada anak dalam memanfaatkan teknologi namun harus bisa dipertanggungjawabkan.

\section{Peran Masyarakat}

Masyarakat dalam kapasitasnya sebagai konsumen teknologi hendaknya perlu memfilter teknologi yang masuk ke dalam masyarakat. Dalam era globalisasi tentu masyarakat harus sadar bahwa kita sebagai masyarakat timur harus mampu mencerna teknologi yang bermanfaat bagi kemajuan masyarakat kita.

\section{METODE PENELITIAN}

Metode penelitian kualitatif dengan pendekatan deskriptif merupakan langkah-langkah representatif objektif tentang gejala-gejala yang terdapat di dalam masalah yang diselidiki. Sehingga memusatkan pada pemecahan masalah yang ada pada masa sekarang. Menurut Miles dan Huberman (1992:15) data kualitatif berwujud kata-kata bukan merupakan rangkaian angka, yang telah dikumpulkan melalui cara observasi, wawancara, intisari dokumen, pita rekaman dan selanjutnya di proses melalui pencatatan, pengetikan, penyuntingan atau alih tulis. Lokasi penelitian berada di Desa Ngadirojo, Kecamatan Ngadirojo, Kabupaten Pacitan. Sumber data di bagi menjadi dua, yaitu data primer yang berupa hasil wawancara dengan perangkat desa dan warga Desa 
Ngadirojo. Alasan memilih lokasi Desa Ngadirojo adalah karena di desa ini pengetahuan tentang literasi media terutama terhadap penggunaan smartphone dengan bijak masih kurang. Sedangkan data sekunder peneliti peroleh data desa yang ada di Desa Ngadirojo. Metode pengumpulan data dengan cara observasi, wawancara, dan dokumentasi. Analisis data yang digunakan peneliti selama penelitian dilakukan, memiliki alur kegiatan yang mengambil model analisis data dari Miles, Huberman, dan Saldana (2013:12) yang terdiri dari kondensasi, penyajian data, dan penarikan kesimpulan. Keabsahan data merupakan standart untuk melihat derajat kepercayaan dan kebenaran dari hasil penelitian, yang meliputi derajat kepercayaan, (credibility), keteralihan (transferability), kebergantungan (dependability), dan kepastian (confirmability).

\section{HASIL DAN PEMBAHASAN}

\section{Literasi Media Masyarakat di Desa Ngadirojo, Kabupaten Pacitan}

Menurut Potter (2004), literasi media merupakan sebuah prespektif yang dapat digunakan ketika sedang berhubungan dengan media untuk menginterpretasi makna suatu pesan yang diterima. Seseorang akan membangun prespektif tersebut berdasarkan struktur pengetahuan yang terkonstruksi dari kemampuan menggunakan informasi. Dalam membagikan informasi, mayarakat cenderung membuatnya dalam bentuk status atau foto profile dengan tujuan agar dapat terlihat oleh publik. Hal ini menunjukkan bahwa pengguna smartphone telah mengetahui bagaimana cara untuk mengoperasikan serta menggunakan strategi yang tepat dalam menyebarluaskan informasi.

Kemampuan dalam memahami konten dan fungsi media sosial, pengetahuan tentang regulasi media, serta perilaku penggunan media sosial di masyarakat Desa Ngadirojo masih minim. Menurut Tibbo (2003), di dalam pengecekan informasi (verifying) terdapat proses menilai serta memeriksa keakuratan informasi yang mereka cari dari berbagai sumber. Sikap masyarakat ketika mendapatkan informasi baru di media sosial menunjukkan bahwa mereka akan membagikan informasi tersebut tanpa melakukan kroscek terlebih dahulu, hal ini menunjukkan bahwa karakteristik masyarakat di Desa Ngadirojo dalam menganalisa konten tidak terlalu baik. Pemahaman akan UndangUndang Informasi dan Transaksi Elektronik tampaknya masih belum dipahami oleh sebagian besar masyarakat di desa ini.

Mengenai jaringan relasi dan pola komunikasi di media sosial, banyak diantara mereka sengaja mencari dan membangun relasi baru sebanyak banyaknya dengan tujuan untuk mendapatkan lebih banyak informasi. Beberapa kegiatan seperti chatting, berkomentar, menulis status, hingga membagikan postingan orang lain merupakan bentuk komunikasi yang dilakukan masyarakat di Desa Ngadirojo. Selain itu, masyarakat juga sering memberikan komentar terhadap status orang lain. Horrigan (2002) mengungkapkan 
bahwa pemanfaatan berbagai fitur seperti berkomentar dan chatting merupakan bagian dari kesenangan yang didapatkan dari media sosial.

Tujuan utama masyarakat lebih banyak berinteraksi dengan smartphone yang mereka adalah karena alasan untuk mencari informasi dan bermain game. Selain itu, juga diketahui bahwa smartphone merupakan perangkat yang sangat penting dan tidak dapat dilepaskan dari kehidupan masyarakat di Desa Ngadirojo.

Kemampuan literasi media masyarakat di Desa Ngadirojo menunjukkan bahwa mereka memiliki kemampuan cukup baik dalam mengoperasikan dan juga memanfaatkan konten dan aplikasi dalam smartphone, namun tidak diiringi dengan kemampuan menganalisa konten media sosial tidak terlalu baik.

Dampak yang paling dirasakan oleh masyarakat di Desa Ngadirojo adalah penurunan prestasi belajar yang dialami oleh putra putri mereka. Selain itu, kurangnya interaksi ketika bertemu langsung dalam situasi seperti pertemuan warga yang rutin digelar juga mulai dirasakan karena hampir setiap orang lebih memilih memainkan dengan smartphone nya ketimbang harus bercakap-cakap langsung. Inilah yang mulai dikhawatirkan oleh masyarakat di Desa Ngadirojo mengingat hampir seluruh masyarakatnya telah memiliki dan menggunakan smartphone.

Smartphone dan berbagai fitur di dalamnya memang sangat menunjang berbagai macam kebutuhan dan aktivitas masyarakat, seperti jual beli, berkomunikasi jarak jauh, menghilangkan stress, memudahkan dalam berkoordinasi, menerima dan menyebarkan informasi yang positif, dan sebagainya. Akan tetapi apabila hal tersebut tidak dilakukan dengan bijak maka mereka harus bersiap menghadapi gempuran dampak negatif yang diakibatkan olehnya.

\section{SIMPULAN}

Berdasarkan pembahasan dari penelitian ini maka dapat ditarik simpulan bahwa lima orang perwakilan masyarakat Desa Ngadirojo memiliki kemampuan mengakses smartphone beserta konten yang ada di dalamnya belum dilakukan secara kritis sedangkan kemampuan mengevaluasi dan memproduksi pesan belum dilakukan secara mendalam.

Masyarakat Desa Ngadirojo sangat aktif dalam mengakses media sosial, game, dan layanan berbasis online lainnya yang merupakan sesuatu yang penting dan tidak dapat dilepaskan dari kehidupan masyarakat di Desa Ngadirojo, mengingat besar masyarakatnya sudah memiliki smartphone yang dapat terhubung ke media sosial dan berbagai fasilitas lainnya dengan sangat mudah. 
Kemampuan mengoperasikan dan juga memanfaatkan media sosial sudah cukup baik sedangkan dalam mengakses media sosial, mereka dapat memanfaatkan sebagian besar fitur yang ada tanpa suatu kendala, namun mereka masih memiliki keterbatasan dalam berbagai hal yang berkaitan dengan pemahaman terhadap isi informasi, pengetahuan regulasi media, dan juga perilaku penggunaan media sosial. Berdasarkan data yang diperoleh, pengguna smartphone akan mencari teman yang banyak untuk menjalin relasi dan mendapatkan informasi hal ini disebabkan karena kuatnya pengaruh teman, adanya ikatan yang terjalin dalam kelompok karena adanya suatu kesamaan hobi maupun tujuan.

\section{DAFTAR PUSTAKA}

Darmastuti, Rini dkk. (2012). Literasi Media dan Kearifan Lokal: Konsep dan Aplikasi. Yogyakarta: Mata Padi Pressindo.

Devito, Joseph A. (2008). Essentials of Human Communication, 6th Edition. Boston: Pearson Education, Inc.

Effendy, Onong Uchjana. (1984). Ilmu Komunikasi (Teori dan Praktek). Jakarta: PT. Remaja Karya.

Faizal, Ahmad Riza. (2012). Apa Makna Literasi Media Sesungguhnya?. Artikel dalam Buku Meretas Jalan Sosialisasi Literasi Media di Indonesia. KPI Pusat.

Jefkins, Henry. (2009). Confronting The Challenges of Participatory Culture: Media Education for The 21st Century. Illinois: MacArthur Foundation.

Kellner, Douglas. (2010). Budaya Media: Cultural Studies, Identitas dan Politik: Antara Modern dan Postmodern. Yogyakarta: Jalasutra.

Kriyantono, Rahmat. (2006). Teknik Praktis Riset Komunikasi. Jakarta: Prenada. Kusuma

Lutviah. (2010). Citizen Jurnalisme Berbasis Blog Group dan Penerapannya Untuk Literasi Media: Studi Kasus Kompasiana.com. www.pustaka.ut.ac.id/dev25/pdfprosiding2/fisip201018.pdf. Diakses 5 Desember 2015

Mulyana, Deddy. (1999). Nuansa-Nuansa Komunikasi. Bandung: Remaja Rosdakarya

Muttaqin, Misbah. (). Kemampuan Literasi Media (Media Literasi di Kalangan Rural di Kabupaten Lamongan).

Ngafifi, Muhamad. (2014). Kemajuan Teknologi dan Pola Hidup Manusia Dalam Perspektif Sosial Budaya. Jurnal Pembangunan Pendidikan: Fondasi dan Aplikasi Vol. 2 No. 1 
Retnowati, Yuni. (2015). Urgensi Literasi Media Untuk Remaja Sebagai Panduan Mengkritisi Media Sosial. Jurnal Perlindungan Anak dan Remaja. AKINDO. Yogyakarta.

Tamburaka, Apriadi. 2013. Literasi Media: Cerdas Bermedia Khalayak Media Massa. Jakarta: Rajawali Pers.

Yusup, M. Pawit dan Priyo Subekti. 2010. Teori dan Prektek Penelusuran Informasi: Information retrieval. Jakarta: Kencana Prenada Media Group. 